\title{
Postface: Robinson(g)
}

\section{Kolja Mićević}

Solitaire à mon îlot matelot sans mât cent yeux demi-clos je transforme ma

force en mille flots: une magique mathématique me pilo -te et j'aime à

la folie cet îlot immobile ! l'exil au doux goût amer ...

Rêver donc au seuil d'une tierce amé -rique, est mon conseil. 